\title{
Local Wisdom of Kembar Mayang In Wedding Tradition of Jawa Ethnic
}

\author{
Hidayati \\ Faculty of Language and Communication \\ Harapan University Medan \\ Email: yatihida853@gmail.com
}

\begin{abstract}
The research is concerned with the local wisdom of Kembar Mayang in wedding tradition of Jawa ethnic. Local wisdom can be in the forms of knowledge, skills and policies used for the welfare of the peoples concerned. Tied to this, Kembar Mayang, about a meter in height, has been known as a pair of symbolic ornaments made of janur or coconut leaf, trunks of banana tree, fruits and flowers of five colors and usually presented in the wedding tradition of Jawa ethnic. The research is conducted by means of descriptive qualitative method and supported by phenomenological approach. Data collection technique and procedures cover observation, interview, questionnaire and documentation with 20 key informants consisting of community leader, scholars, and community members. The results show that there are four points of local wisdom in Kembar Mayang: Maintaining Family Honour, termed keris-kerisan in the form of dagger-shaped webbing; Mutual Protection, termed payungpayungan in the form of umbrella-shaped webbing; Fidelity, termed manuk-manukan in the form of bird-shaped webbing; Tenacity and Sacrifice, termed walang-walangan, in the form of praying mantis-shaped webbing. Kembar Mayang as a cultural heritage is to be preserved to be used as a guideline in social life.
\end{abstract}

Keywords: local wisdom, Javanese Culture, Kembar Mayang

\section{Introduction}

Indonesia is a unitary state crossed by the equator. Indonesia is located between Australia and the Asian Continents. In addition, Indonesia is also the largest archipelago country and is located between two large oceans, the Pacific and the Indian Oceans.

As an archipelago country Indonesia has a diversity of cultures, races, ethnic groups, beliefs, religions, regional languages, and many others. Although full of cultural diversity, Indonesia remains one according to its slogan, Bhineka Tunggal Ika, meaning unity in diversity. Diversity is a condition in people's lives. The diversity in Indonesia is a wealth 
and beauty of the Indonesian nation reflected from the culture of each region as a representation of a particular ethnicity. People belonging to a particular ethnic group, must have the awareness and identity of the tribal culture of the nation, for example in the use of local languages and love for the arts and customs.

Bastomi in his book Appreciation of Traditional Art (1988) explains that tradition is a spirit of culture strengthening the cultural system. Tradition has always been tested from the point of effectiveness and efficiency, and always attends to the development of cultural elements. Tradition can take the form of attitude or action in overcoming the problem.

In other words, a tradition is a collection of material things or an idea that is given a special meaning from time to time. Tradition is a picture of attitudes and behavior of people having been in process for a long time and carried out from generation to generation. Entrenched tradition will be a guideline for a person to conduct. (Zasya and Rini, 2018)

Tradition, by means of which relationships between individuals and their communities can run harmoniously, is the spirit of a culture, making the cultural system solid and If eliminated, there is a possibility that a culture will end as well. (Soekanto, 1990)

Tradition, closely related to local wisdom, often referred to as custom, is an activity carried out by a group of people from generation to generation with the aim to obtain harmony either between humans with humans or harmony between humans with nature through values and norms contained in the tradition. If this harmony can be achieved and maintained, then the welfare can be easily obtained. Welfare is not only concerned with matters but also with spiritual relevance.

The values and norms that exist within a tradition will generate local wisdom. Local wisdom is an idea or wisdom inherited from previous generations and used as a reference in living social life in harmony.

Thus it can be seen that the local wisdom is an intelligence of a community derived from experience in social life and experience. The experience will be a common property and serve as a source or reference in solving problems, such as local wisdom of Javanese tradition; this means that the experience of Javanese ethnic life is contained in the tradition carried out periodically as a source of enlightenment for the social life of Java communities. In addition to various features of social activities in the form of tradition, the tribes in Indonesia also have the works of art in the form of objects such as painting, sculpture, batik, and webbing.

One of the works of art produced through the activities of cultural traditions and also has the values of local wisdom is Kembar Mayang from Jawa ethnic. The points of local wisdom of Kembar Mayang in wedding tradition of Jawa ethnic are four: Maintaining Family Honor, termed keris-kerisan in the form of dagger-shaped webbing; Mutual 
Protection, termed payung-payungan in the form of umbrella-shaped webbing; Fidelity, termed manuk-manukan in the form of bird- shaped webbing; Tenacity and Sacrifice, termed walang-walangan, in the form of praying mantis- shaped webbing. ${ }^{1}$ These four points become the focus of this research.

Jawa ethnic, as one of the largest ethnic groups in Indonesia has diverse cultures. Some people assume that what is meant by Jawa ethnic are people born in and inhabiting the area of West Java, Central Java and East Java and speaking Javanese language. However, in reality in addition to those three provinces, many Javanese people are found in other regions of Indonesia, including Medan, the capital of the province of North Sumatra. (Suryadinata, et.al., 2003)

The Javanese are also known to be very flexible and easy to interact with other tribes; that is why the Javanese people can live anywhere, and this causes the spread of Javanese tribe to all regions in Indonesia. Overall, Javanese people speak Javanese language; there are only dialect differences in certain areas.

Jawa ethnic strongly adheres to tradition or customs that they have and always carry them out well. For Javanese people, if there are some Javanese people who do not do the Javanese traditions or customs, they will be considered weird and often get reproached from the surrounding communities. The term for the Javanese is more identical for the people who adhere to the philosophy of customs. ${ }^{2}$

In the philosophy of life, the Javanese strongly uphold the balance, and harmony of life both to human beings as well as with the natural environment. In their everyday ethics, they put forward the norms of decency, politeness and simplicity. (Kartodirdjo, 1975)

Javanese culture, having values of nobility and cultural wisdom, is one of the cultures owned by the Indonesian people. Every tradition in Javanese community has deep and noble philosophical meanings. One of the important traditions in Javanese community is marriage.

Marriage is a series of ceremonies conducted by two human beings to justify all deeds that have to do with the life of husband and wife, aiming to create a family and also continue the lineage. In general, marriage in Javanese ethnic starts from the consideration of social, cultural and educational background of the bride and groom to be.

\section{Literature Review}

This study relates to local wisdom found in cultural object termed Kembar Mayang in wedding tradition of Jawa ethnic. Local wisdom can be interpreted as a system in the social, political, cultural, economic, and environmental orders existing in the local

\footnotetext{
${ }^{1}$ Interview result.

${ }^{2}$ Interview result.
} 
community based on clear reason, and containing positive things. Through local wisdom people could make difference between local and modern cultures.

Local wisdom is a set of ideas or policies based on the values of virtues found in a community and often applied, believed to be the guidance of life, and handed down from time to time. Local wisdom can be in the forms of knowledge, skills and policies used for the welfare of the peoples concerned. Local wisdom is of two forms, tangible and intangible. Tangible local wisdom appears in the forms traditional text, traditional buildings and cultural symbol; while the intangible one in the abstract forms such as advice or proverb. (Manugeren, et. al, 2017)

Local wisdom, from linguistics anthropology perspective, is a part of values and norms of an oral tradition inherited from one to another generation through oral ways. Some forms of local wisdom are hard work, discipline, education, health, gender standing, cultural and creative reviving, peace, mannerism, honesty, solidarity, care-free life style, conflict-solution, commitment, positive thinking and gratefulness (Sibarani in Manugeren, et. al, 2017)

Furthermore, local wisdom should be the foundation of a marriage so that the couples involved can run their marriage life in harmony. According to the LAW OF THE REPUBLIC OF INDONESIA NUMBER 1 YEAR 1974, ABOUT MARRIAGE: Chapter I: Marriage Base, verse 1: Marriage is a mental bond between a man and a woman as husband and wife in order to form a happy and eternal family based on the belief in the only one God. (DPR RI, 1974)

Marriage according to Javanese custom is an effort to present and synergize the concepts of microcosm and macrocosm together; a spiritual and cultural journey whose application boils down to society. And if the two world concepts are not synergistic, then disharmony becomes the consequence. Thus marriage is a sacred event that must be respected through the existing traditions. (Bratawijaya, 2006)

\section{Research Method}

The research was conducted by means of descriptive qualitative method, proposed by Miles and Huberman (1994) and supported by phenomenological approach. Phenomenology is basically concerned with lived experience having a focus on the experience and the perspective of the participants. (Georgi, 2012). Descriptive qualitative method is commonly used in social sciences to describe the existing phenomenon and in this matter concerned with Kembar Mayang used in Javanese wedding tradition. The goal was to describe in details significant parts of Kembar Mayang to expose the points of local wisdom. The data were obtained from various Javanese wedding tradition in Medan city, province of North Sumatra, Indonesia. Data collection technique and procedures cover observation, interview, questionnaire and documentation. In-depth interviews were conducted with 20 key informants consisting 
of community leader, scholars, and community members. In addition, triangulation technique was also use to crosscheck the data validity.

\section{Discussion}

Kembar Mayang is to be made two, symbolizing that the bride and groom must be in the same feeling and must be able to maintain the integrity of the household; no matter how difficult the obstacle might come.

Aside from being a part of a wedding procession, Kembar Mayang is also used for some other ceremonies, among which are as a medium for casting out bad omen, or showing and expressing respect for a person or group thought to have made something good for the sake of the community. This is tied to the process of making Kembar Mayang which must go through a series of conditions such as prayer, sincerity of heart and love. ${ }^{3}$

In addition, Kembar Mayang must be done at one time and should not be delayed. This implies the symbol that marriage must be done once in a lifetime. Another requirement is that Kembar Mayang must be done in a good and clean place, symbolizing that marriage must be done with a loving and clean heart. ${ }^{4}$

\subsection{Keris-kerisan - Symbol of Maintaining Family Honor}



Nothing is perfect in this world; so it is with humans. Anyone in this world, male or female, must have positive or negative side. This should be the basis for establishing a relationship, especially the relationship between husband and wife. The couple must realize that everything has been planned and determined by God. This means that the happiness of a household is not determined by the positive sides or the deficiencies owned by each partner; moreover, if only measured from the physical condition of the couple. The real quality required is concerned with morality tending to attitude.

At times some people forget this and they lightly talk about the deficiencies of their partner to others. Unconsciously, such disgrace continues to become a habit. Ideally in a household, the principle of mutual care should be prioritized. It is ironic if the couple mutilate each other. Thus the couple does not need to mutilate or blame each other, let alone getting to a third party because there is no partner who has no negative side. Maintaining the honor of the family is an obligation for the couple and this is an

\footnotetext{
${ }^{3}$ Interview result.

${ }^{4}$ Interview result.
} 
important factor to gain a harmonious family life. Harmonization in a family relationship will only be achieved with the support of the couple concerned. (Bosch, 2007)

Associated with the implementation of Kembar Mayang, maintaining the honor of the family is a local wisdom that is reflected from one part of Kembar Mayang, which is woven in the form of a dagger and called keris-kerisan. Keris is a casual weapon used to defend oneself from all forms of danger. Therefore, with local wisdom in the form of maintaining the honor of the family, married couple should be more vigilant in running a household life. They must be able to fortify themselves with positive action so that households are not disturbed as small things can damage the relationship that have been fostered so long.

\subsection{Payung-payungan - Symbol of Mutual Protection}

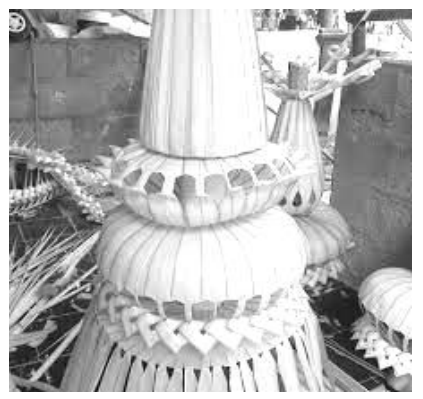

The next part of Kembar Mayang is an umbrella-shaped webbing and is called payungpayungan. The main function of the umbrella is as a protective device from the sun and rain. Although the sun is shining with heat and the air is very hot or when it rains, people with umbrellas will still be able to continue their journey towards their destination. So the philosophy of an umbrella is readiness to provide protection.

The local wisdom contained in this section is that married couple has to protect each other. A husband is obliged to protect his wife and otherwise a wife is also obliged to protect her husband. This mutual protection certainly makes their relationship more solid and not easily shaken with the exposure to all forms of issues. (Parker, 2002)

Marriage is the beginning of a long series of worship in a family life. Every goodness done in marriage has a value of worship. Family harmony can be maintained with love, sincere affection, sincere devotion, attention, communication, mutuality of quality of life, and mutual correction and another important thing is mutual protection.

The term "husband" and "wife" is a legal statement, indicating that both of them have been bound by a legal marriage. But in essence, they must be very special friends, not strangers. They must be closer to each other every time. If husband and wife keep their distance from each other, they will make their interaction very formal and have no intimacy, and surely this could be an imminent breakdown. The point is they have to protect each other. 
Mutual protection basically has the meaning that they share a sense of joy and sorrow. They help each other and lighten each other's burdens, due to the strong bonding of feelings they have in themselves. They will share happiness as well as sadness or difficulty.

\subsection{Manuk-manukan - Symbol of Fidelity}

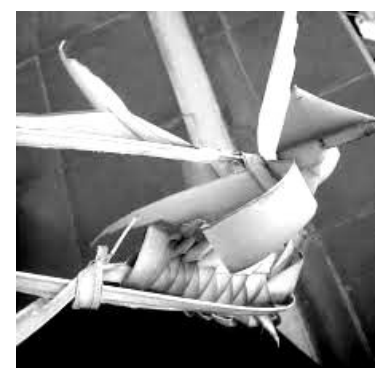

Fidelity is one of the cornerstones of marriage, as essential as emotional support, trust, and commitment. (Pascale and Loius, 2016)

The third part of Kembar Mayang is a bird-shaped webbing that symbolizes the importance of loyalty in running a marriage life. ${ }^{5} \mathrm{~A}$ commonly accepted view is that the morality of marriage depends upon fidelity. (Cicovacki, 1993) and this view is then supported by Pascale and Louis (2016) stating that fidelity is one of the cornerstones of marriage, as essential as emotional support, trust, and commitment.

Almost everyone expects husband and wife to be faithful, in the sense of not having sex with someone who is not life partner. This view of fidelity in marriage is in harmony with the norms of society which suggest that marriage will be honorable if it is not polluted by any relationship with a third party.

Fidelity is one of the most important factors in marriage. Even the promise to always be faithful pronounced in the wedding is not an easy thing to do. Divorce often occurs with the reason of the presence of a third person in marriage. There are many things that could be the cause why couple end up turning to others; so it is necessary to have selfintrospection from each side as to why this can happen and it is necessary to work hard to restore the damaged relationship because of this disloyalty issue. That is why at the beginning of marriage there must be a commitment made not for some reason but with full awareness.

Fidelity in marriage is indeed very special, because keeping fidelity is not something easy. So if the married couple can uphold fidelity, they have achieved remarkable achievements. The relationship in marriage usually undergoes various challenges, and if the relationship is not based on fidelity, then marriage will not last.

The shape of the bird in Kembar Mayang symbolizes eternal love through the symbol of the dove. Dove is a bird that is often used as a symbol of love in marriage. In addition,

\footnotetext{
${ }^{5}$ Interview result.
} 
doves are birds that are faithful to the partners. Unlike some animals or birds that alternate couples to breed, pigeons are birds that are faithful to their partners. Pigeon pairs are usually one for the rest of life. That is the reason why doves often serve as a symbol of fidelity in relationships. ${ }^{6}$

\subsection{Walang-walangan - Symbol of Tenacity and Sacrifice}

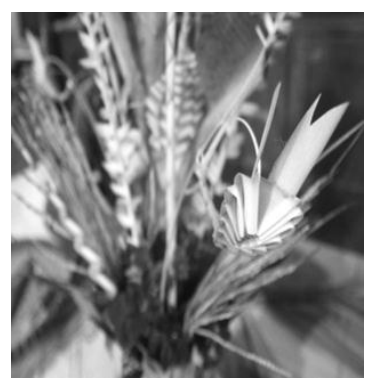

Those that have tenacity will not quit when confronted by obstacles or when failing. In a game or in life, tenacity wants to win, and tenacity lives by the credo, "Failure is not an option." When failure is imminent, tenacity is the inner voice that declares, "I will not be denied!" Whether it is known as willpower, determination, or persistence, it is the key to success. It pushes one to one's limits because it will not accept anything less than one's best. In the end, people with tenacity will win or break themselves trying, but just by giving their all, they have grown. (Allard: 2003)

The next local wisdom of Kembar Mayang is persistence and willingness of sacrifice symbolized through walang-walang or walang kekek and in English termed praying mantis. ${ }^{7}$

Praying mantis is a very persistent insect in foraging and with the ability to camouflage it can easily find food. In addition, the female praying mantis will soon eat the heads of the male one as soon as they finish their copulation. Although the male knows that he will be eaten by the females he does so in order to maintain the survival of the praying mantis and the female praying mantis will also die shortly after she spawns.

The persistent or unyielding attitude and also willingness to sacrifice possessed by praying mantis is an important epitome for married couple in running household life. Persistence is unyielding spirit followed by strong and steady beliefs to achieve dreams and aspirations. This value is needed by humans to always have a great spirit and not easily despair in achieving goals.

Lack of enthusiasm and perseverance in realizing the dreams makes the ideals and hopes will only be a wishful thinking. Ideals will be the goal and accomplishment if someone makes the effort leading to these ideals. Herein the importance of persistence lies. A person who has a strong tenacity will make the effort lead him to achieve his goals. Persistence is the champion's mentality as persistence will encourage someone to work

\footnotetext{
${ }^{6}$ Interview result.

${ }^{7}$ Interview result.
} 
and learn harder. Persistence will make a person fearless to try again, even if he or she has failed.

Likewise, with the willingness to sacrifice for a positive thing. In a domestic life, a man must be ready to sacrifice for the happiness of his family, his wife and children; while a woman or a wife is naturally ready to sacrifice for her family, her husband and her children. Taking care of husbands and raising children is a huge sacrifice.

When a man is serious and earnest in his relationship, he will do his best for his beloved wife. There is never any intention to disappoint or upset her. He will be able to work and struggle harder than usual in order to provide the best comfort for his wife. A true man will make his wife and family his source of motivation in trying.

Thus persistence to uplift the dignity of family and the willingness to sacrifice in all things for the sake of the family is a noble attitude that must be owned by married couple if they want to succeed in fostering a household. The meaning of success in a household is the achievement of harmonization in relationship.

Noller in Stanley (2006) finds that people identify sacrifice, along with caring, trust, respect, and loyalty, as part of their conception of what "love" means. Further, numerous findings from the altruism literature suggest that the more closely a person is related to another, the more likely that person is to give up something in order to help the other. (Stanley, et.al: 2006)

\section{Conclusion}

Wedding tradition of Javanese people is attached to ubarampe called Kembar Mayang, that is a pair of symbolic ornaments made from of janur or coconut leaf, trunks of banana tree, fruits and flowers of five colors. Two Kembar Mayang are made the day before the wedding, about a meter in height.

Kembar Mayang is one of the important apparatuses in wedding tradition of Javanese ethnic. Each part of Kembar Mayang has a symbol of prayer and family hope that the whole series of wedding processions can go well and then married couple gets a blessing to run the life of the household.

Kembar Mayang is a cultural heritage that has been used from time to time. The use Kembar Mayang in the Javanese wedding tradition is not merely a decoration to be exhibited but also contains function, meaning and value of art and culture, beneficial to the whole society especially the newly married couple.

Each part of Kembar Mayang has a philosophical meaning that contains local wisdom for character building. The points of local wisdom of Kembar Mayang in wedding tradition of Jawa ethnic are four: Maintaining Family Honor, termed keris-kerisan in the form of dagger-shaped webbing; Mutual Protection, termed payung-payungan in the 
form of umbrella- shaped webbing; Fidelity, termed manuk-manukan in the form of birdshaped webbing; Tenacity and Sacrifice, termed walang-walangan, in the form of praying mantis- shaped webbing.

Kembar Mayang is a cultural heritage that must be preserved. Everyone should realize that the value contained in an inheritance has meaning and value that can be used as a reference in life. The wealth of cultural heritage must be maintained, cared for and socialized to the world for the inauguration of identity as a nation of dignity.

\section{References}

Allard, Sheila. (2003). Tenacity: Vital to Success. Wink: An Online Journal. Retrieved from https://www.westerntc.edu/sites/default/files/student-life/documents/ HeckmanL.pdf on 22 June 2018.

Bosch, Kathy, Marilyn Fox, Gail Brand. (2007). Strengthening the Couple Relationship. NebGuide. Nebraska: University of Nebraska. http://extensionpublications.unl.edu/assets/pdf/g1716.pdf.

Bratawijaya, Thomas Wiyasa. 2006. Upacara Perkawinan Adat Jawa. Jakarta: Pustaka Sinar Harapan.

Cicovacki, Predrag. (1993). On Love and Fidelity in Marriage. Journal of Social Philosophy. Volume 24, Issue 3. Retrieved from https://onlinelibrary.wiley.com/doi/pdf/10.1111/i.1467-9833.1993.tb00527.x on 28 June 2018.

Dewan Perwakilan Rakyat Republik Indonesia. UNDANG-UNDANG REPUBLIK INDONESIA NOMOR 1 TAHUN 1974 TENTANG PERKAWINAN. Retrieved from http://www.bphn.go.id/data/documents/74uu001.pdf on 20 June 2018. 1974

Georgi, Amedeo. (2012). The Descriptive Phenomonological Psychological Method. Journal of Phenomonological Psychology. Vol. 43, Issue 1. Retrieved from http://booksandjournals.brillonline.com/content/journals/10.1163/15691621 2x632934 on 21 June 2018.

Kartodirdjo. (1975). Sejarah Nasional Indonesia. Jakarta: Departemen Pendidikan dan Kebudayaan, Jakarta.

Manugeren, M. et.al. (2017). Local Wisdom in Hindu Tamil Ethnic Wedding Tradition in Medan. RET Academy for International Journals of Multidisciplinary Research. Vol 5, Issue 7. Retrieved from www.raijmr.com on 12 June 2018.

Miles, MB. \& Huberman, AM. (1994). Qualitative Data Analysis (2nd edition). Thousand Oaks, CA: Sage Publications.

Parker, Robyn. 2002. Why Marriages Last. A discussion of the Literature. Australian Institute of Family Studies. https://aifs.gov.au/sites/default/files/publicationdocuments/RP28.pdf.

Pascale, Rob and Louis H. Primavera. (2016). Making Marriage Work. Lanham, Maryland: Rowman \& Littlefield Publishers.

Soekanto, Soejono. (1990). Sosiologi Suatu Pengantar. Jakarta: PT Raja Grafindo Persada. 
Stanley, Scott M, et. al. (2006). Sacrifice as Predictor of Marital Outcomes. Family Process Journal. Vol. 45, No. 3. Retrieved from http://public.psych.iastate.edu/ccutrona/psych592a/articles/sacrifice.pdf on 22 June 2018.

Suryadinata, Leo, Evi Nurvidya Arifin and Aris Ananta. (2003). Indonesia's Population: Ethnicity and Religion in a Changing Political Landscape. Singapore: Institute of Southest Asian Studies.

Zasya, Taufan and Rini Noviana. (2018). Tradisi dan Kaitannya dengan Kebudayaan. Era. Id. Retrieved from https://www.era.id/read/XRUx3P-tradisi-dan-kaitannyadengan-kebudayaan on 20 June 2018. 